\title{
Superficial Monoclonal Gastrointestinal Tract T-Cell Infiltrate Present
}

National Cancer Institute

\section{Source}

National Cancer Institute. Superficial Monoclonal Gastrointestinal Tract T-Cell Infiltrate

Present. NCI Thesaurus. Code C139022.

A morphologic finding indicating the presence of a superficial monoclonal T-lymphocytic infiltrate in the gastrointestinal tract. 